\title{
Gambling on land fill and infrastructure to reposition Macao in the Pearl River Delta
}

\author{
John Zacharias
}

\begin{abstract}
Introduction: Emerging regions worldwide increasingly involve cross-border relations. The Pearl River Delta (PRD) in south China in particular has been the focus of investigation in the recent literature on multiple jurisdiction regions, but with very little attention to Macao. Macao's position in the region differs from that of Hong Kong, the other Special Administrative Region (SAR), for historical, economic and geopolitical reasons. Gaming has delivered wealth, along with social problems and growing dependency on the Mainland on a land base that is very small and geographically complex. Breaking out of its isolation as a post-colonial backwater involves redefining the relationship with neighbouring Zhuhai on the Mainland with hopes for stronger links with Hong Kong.

Case description: An ambitious reclamation project will add about 350 ha of land to the territory, including underground space and transport infrastructure.

Discussion and Evaluation: Commodifying the new territories engages the Macao SAR in a role complementary to that outlined for Zhuhai. The gamble is that real estate-led development will support an economy that continues to depend largely on gaming. While the focus in the burgeoning literature on emerging regions is almost exclusively on institutional and economic integration, this paper looks at how cross-border integration may also involve urban plans.
\end{abstract}

Conclusions: It is argued that extra-territorial pressures and rescaling of governance in the PRD are drivers for the development plans now being implemented.

\section{Background}

In the last several years, there has been much research on emerging regions under the forces of globalisation, particularly those involving multiple states, intra-state regional authorities and cities, as well as supra-territorial agencies. It is argued by several investigators (Otgaar et al., 2008; Shen, 2014; Luo and Shen, 2012) that regional integration takes different forms and engages different scales across the globe. For example, European cities have focussed on urban policies while leaving regulatory and macro-economic matters to state and inter-state authority (Brenner, 2004). By contrast, in the PRD, institutional integration has lagged behind economic integration (Shen, 2014). In fact, the PRD appears to be a significant exception in Brunet-Jailly's (2005) thesis that closer economic ties are accompanied by cooperative institutional arrangements and eventually by social integration. While economic integration between

Correspondence: zachariasjohn478@gmail.com

College of Architecture and Landscape, Peking University, (Zhongguancun North Street), Beijing (100080), China
Hong Kong and Shenzhen in particular has been rapid and of immense proportions, significant tensions have arisen in the social sphere and to a lesser extent at the institutional level (Yang and Li, 2013). Macao's economic integration with its Mainland partner, Zhuhai, is quite different from that of Hong Kong and with the relative absence of obvious conflictual relations.

Integration has often led to imbalances across the region (Timberlake et al., 2014), which may also fuel intraregional rivalry and difficulties in forging cooperative arrangements ( $\mathrm{Li}$ et al., 2014). The PRD is a case in point, where a singular focus on the Guangzhou-ShenzhenHong Kong corridor has left peripheral areas and indeed the whole west half of the Pearl River estuary relatively under-developed. Unified labour markets under shortening travel times have also brought enormous disparities in income within individual cities, a source of tension, and an impediment to the hoped-for social pact. City-led development has not addressed these disparity issuesarguably accentuating them-with these issues referred upward to regional and state authorities.

\section{Springer}


Efforts at institutional cooperation have accompanied intensifying competition. Guangzhou and Shenzhen vie for pre-eminence as global business centres in the PRD, aiming to challenge Hong Kong's role as global capital with its financial sector and high concentration of producer services (Sassen, 1991). The west side of the PRD, with smaller cities in a landscape still dominated by agriculture, claims a better environment and higher quality of life. Although Zhuhai is promoting its own central business district, it hopes to achieve second-tier status by adopting the twin city concept promoted by Shenzhen in its relation with Hong Kong (Shen, 2014). Quality of life and access to a less urbanised environment are key advantages of Macao-Zhuhai, as expressed in the Guangdong provincial integration plan of 2009 (Yang and Li, 2013). While Hong Kong has resisted some of these concepts emanating from the Mainland, Macao government has embraced them, as exemplified in the plan discussed below.

This examination of Macao links its recent emergence as a prosperous gambling hub to its development plans for the longer term. The rapid growth of the gaming industry in Macao is well documented, leading to much investigation of the particular nature of the tourism industry in this self-administered part of China, as well as consideration of the social consequences of gaming as an economic mainstay. The recent proposal for a final massive expansion of its landmass has hardly been reported internationally and in particular, has not been related to the new relationship with the Mainland generated by gaming. This topic is important, not only because it represents a bridgehead for Chinese central government policy on its own territory and throughout East and South-East Asia, but also highlights the critical role urban planning can play in this new inter-governmental relationship. The present article reports on an investigation by the author in several visits to the region from 2010 to 2013, a review of local planning reports, attendance and participation in a number of public hearings, and a series of semi-structured interviews with twenty local planners working for the utilities and advisory planning institutes, as well as the consultant planning firms.

The research focusses on the Five-Islands plan, the most significant single development project ever undertaken in Macao and an end-game given the present political arrangements between central government and the SAR. The plans address current needs as defined, while claiming a direction for the long-term future. The proposals also strengthen a dependency on the Mainland, the source of the SAR's prosperity, by joining its own residential development to a new business core for Zhuhai. Similar efforts by Shenzhen to develop Qianhai as a lure for the Hong Kong financial industry and its highly paid workforce have so far been rebuffed. The difference in approach is partly explained by history and partly by the precarious economic prosperity of Macao.
Macao was founded by Portugal in 1557 on peninsular Macao at the mouth of the Zhujiang (Pearl) River. Built as a trading post on the Sea Silk Route, the colony was officially established in 1887 and was granted substantial autonomy by Portugal in 1976, following the overthrow of the dictatorship in Lisbon. The offshore state is also an interesting mosaic of Portuguese colonial culture, Cantonese traditions and a somewhat conflicted relationship with the Chinese central government (Hao, 2011). For example, unlike Hong Kong, Macao citizens generally embraced the new political relationship with Beijing after 1999 while exercising substantial local autonomy.

After the hand-over to China December $20^{\text {th }}, 1999$, the Macao SAR examined its options for development. It lagged far behind prosperous Hong Kong, lacking both the deep-sea port and land base that enabled its sister city to become one of the economic powerhouses of Asia. By comparison, Macao was a quiet backwater, rife with crime, suffering a weak economy, official corruption and a small market (Luke, 2010). In an effort to reposition itself regionally and to promote itself economically, Macao liberalised the gaming industry in 2002, which had until then been a family-run monopoly. Macao became by far the largest gaming centre in the world, with seven times the activity of Las Vegas and 29.3 million visitors in 2013 (Statistics and Census Service 2004). China, which does not have a legal gambling system, finds it convenient to have Macao as a close-by outlet for Mainlanders, who must obtain a permit to visit from the Mainland authorities. The number of visits per individual is restricted and not combinable with a visit to Hong Kong. As a consequence, visitors to Macao have grown dramatically, now exceeding those to Hong Kong. This relatively small city saw its GDP grow very rapidly over the last decade, now fourth per capita in the world. Part of Taipa and a much larger part of Coloane, the southern island, together the so-called Cotai, are now devoted to casinos and related services. Breaking out of its doldrums has so far meant transforming itself into a gambling venue for Mainland Chinese.

While the gaming industry has raised income levels to among the highest in Asia, sudden wealth has come with substantial social problems (Wan, 2012). The school dropout rate has increased as students depart early for lucrative jobs in relatively low-skilled casino work. Gambling addiction has continued to rise, while Hong Kong and Singapore have succeeded in reducing their rates. A rapid rise in crime levels and prostitution has attended the growth in the gaming industry, as they have in other gaming centres (Allock, 2000). While some of the social pathologies are associated with rapid economic growth, observers tend to agree such problems are exacerbated by the dependency on gaming for economic growth (Petry, 2003). Despite these disturbing trends, widely 
recognized by Macao residents, there is relatively high level of satisfaction with the quality of life in the city (Rato and Davey, 2012), along with an acceptance of the gaming industry's role in delivering that quality of life. In a bid to diversify its economy away from heavy dependence on gaming, "leisure activity" and creative industry are now emphasised. The existing landmass makes this diversification effort difficult ( $\mathrm{Hsu}$ and $\mathrm{Gu}, 2010$ ). A large part of the Macao peninsula is occupied by an extensive UNESCO World Heritage site (2005), the original Portuguese settlement, Lingnan-style courtyard homes of the early Chinese business immigrants, churches and military facilities. The remaining territory has been developed at high density to accommodate the Macao Cantonesespeaking majority, now $85 \%$ of the population. In spite of substantial efforts at promotion, these world-class assets have failed to attract increased tourist revenues (Huang et al., 2012), yet the local government remains hopeful that its plan will do just that. All development to date has been built without underground facilities, such that even the parking garages are in elevated structures above the streetlevel commercial floors. A large part of the available land resource and much of the already reclaimed land has been handed over to international gaming interests, who have replicated the Vegas experience for China and Asia (Balsas, 2013). The burgeoning gaming industry has gobbled up nearly all the available land resources, making it very difficult for Macao to service this industry, let alone develop and exploit its rich colonial heritage. Housing the thousands of casino workers is itself an enormous challenge that the existing landmass and urban development cannot meet (Hsu and Gu, 2010). Finally, air pollution and road congestion have accompanied the loss of lands originally destined for housing, public facilities and parks, now occupied by the casinos. Thus, the islands proposal, which excludes any future casino development, is in fact an adjunct to the casino economy of Macao in as much as it aims to service and complete its infrastructure (Luke, 2010).

Although overall economic growth in Macao since liberalisation of the gaming industry in 2002 has been formidable, the financial crisis of 2008 resulted in a sharp drop in growth. In fact, overall revenues actually declined in that year and again in 2014 with the crackdown on corruption and prostitution by the central government. Casino construction projects suddenly halted and there were thousands of layoffs. While few sectors are immune from global economic crises, recent developments on the Mainland underscore the importance of a more diversified approach to local economic development. In addition, arrivals are in the great majority from Mainland China and subject to restriction by Mainland authorities. While the number of allowed visits to Macao was marginally increased in recent years, it is also imaginable that they could subsequently be reduced. A minor change in the regulation could have devastating impact on the casino industry. Singapore and other Southeast Asian destinations are developing casinos to serve a Chinese population that is increasingly on the move.

Across the mouth of the Zhujiang River, Shenzhen prospered after the Reform and Opening Up through inward investment from Hong Kong. Today Shenzhen has twice the population of Hong Kong and is China's fourth city in terms of GDP. Zhuhai enjoyed the same locational advantage with regard to extra-territorial Macao in 1978, but there was little inflow of investment funds from Macao for reasons mentioned above. As a consequence, cities in the western wing of the Pearl River Delta languished in the twenty years following Reform. However, in the last several years, investment in highway infrastructure in particular, along with new bridge crossings to the east have re-invigorated the local economy. The latest overtures of Zhuhai include a Central Business District directly opposite Macao and using the Shizimen Strait as direct access from the sea. Although somewhat removed from the core of present-day Zhuhai, this location is a symbolic invitation for direct inward investment from Macao, while promising integration. Macao is accumulating capital at a formidable rate. Such an approach is quite different from that of Shenzhen, where the proposed CBD of Qianhai is intended to invite the direct transfer of CBD activities from Hong Kong to a new location quite removed from present-day Hong Kong.

Macao SAR has accumulated substantial capital reserves, allowing it to launch an ambitious programme to accommodate continued growth in its population, a diversification of its economy and a final expansion of the land area from the present $29.2 \mathrm{~km}^{2}$. The population increased from 435,000 to 544,000 between 2001 and 2010, largely through the granting of work visas. The plan is to allow the population to increase further by more than 100,000, almost entirely through immigration. The permanent resident population is insufficient to support the booming service industries alone, while Macao's birthrate is well below the replacement level. Thus, sustained economic growth and the attendant population increase, largely in work-visa residents, explain the current effort to expand the landmass and the developed urban area.

\section{The five islands development proposal}

It is important to note that Macao had no planning system in place at the time of the hand-over and has only tentatively proceeded with consultations and formal approvals. At the time of writing, Macao does not have a planning department within the government, but does rely on the services of a consulting Planning Institute. 
This situation contrasts sharply with Hong Kong, with its legacy of formal planning under British rule (Bristow, 1989), and a public system since the hand-over. In 2011, the government launched its first major public consultation on the ambitious expansion of territorial Macao, to reclaim more than $3 \mathrm{~km}^{2}$ of seabed, mostly between the historic peninsula and the conjoined Taipa and Coloane islands, but also off its eastern coast (Figure 1), thus increasing the total land area by about $10 \%$. Various consultancy inputs were used to prepare an options document for public consultation in early 2012 (Macao, 2012). The China Academy of Urban Planning and Design (CAUPD)-a Mainland state-owned consultancy and the largest in China- prepared the final proposal for public consultation.

Further sea reclamations are impossible under the current arrangements between the central government and the SAR, as well as the arrangements made with Zhuhai for access through the Shizimen Strait. The waters surrounding peninsular and island Macao are not part of the SAR, while the reclamations are confined to the narrow Macao-controlled strait between these lands. Nearly half of peninsular Macao is occupied by the
World Heritage Site, one of the most important in Asia and already under considerable pressure from development at its perimeter and within. Coloane is also a sensitive environment, with historic seaside settlements and the largest green space in the territory.

Besides the urban development on the reclamation areas (Figure 1), the proposed customs port (5 in Figure 1) will handle goods travelling between Hong Kong, Macao and Zhuhai. Macao has also managed to strike a deal with Zhuhai, to develop a campus for the University of Macao on Hengqin Island, linked by a bridge to the territory but surrounded by a moat and patrolled security fence. Further colonisation efforts on Hengqin Island, once part of Macao, are likely to be resisted since Macao continues to operate according to its own legal and monetary system, while Zhuhai gains little except financial compensation for the lease of lands.

A bridge was proposed and approved by the Macao government and the Chinese central government that will soon link Hong Kong, Macao and Zhuhai, with the intention of supporting the important role of tourism in the three city economies (Hsu and $\mathrm{Gu}, 2010$ ). Hong Kong approved the building of its end of the bridge only

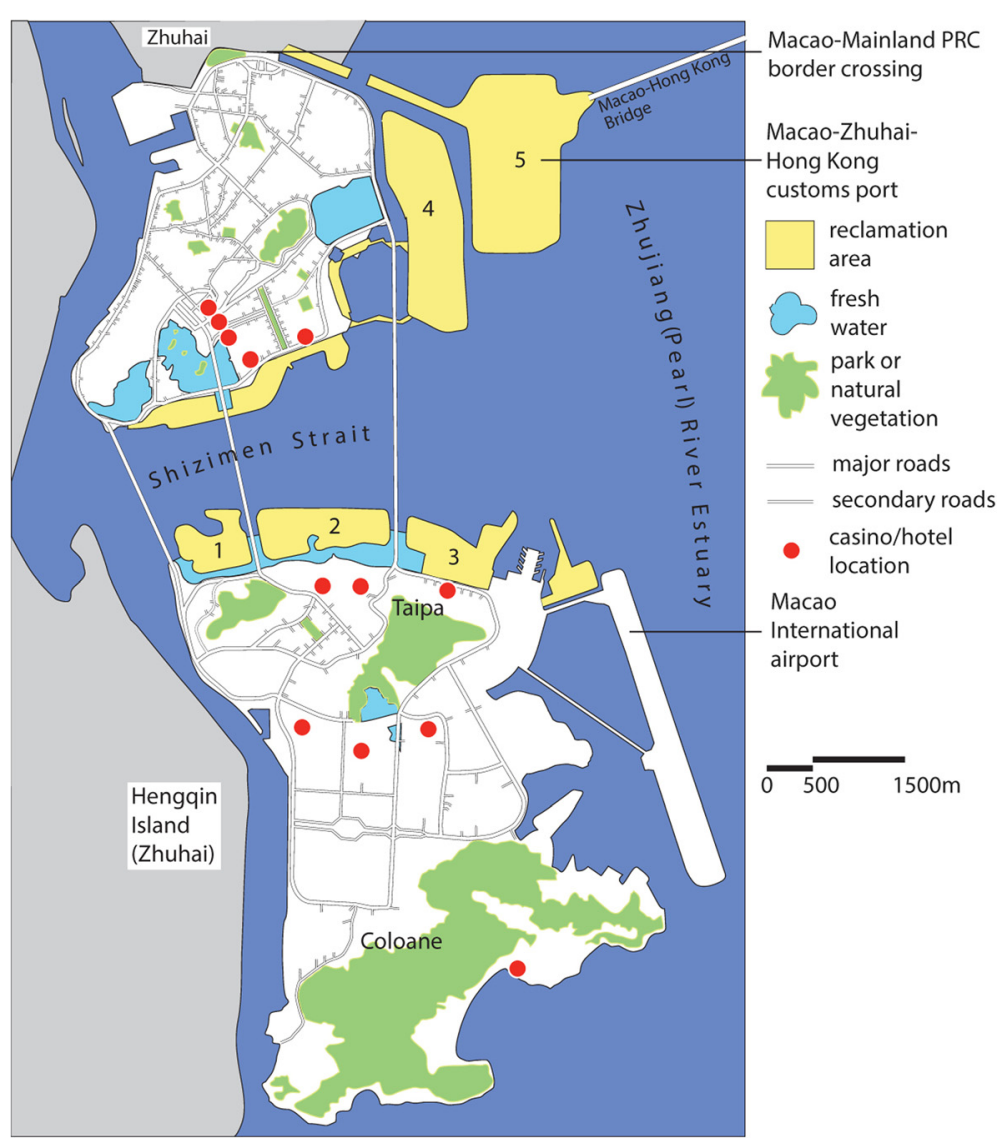

Figure 1 The reclamation areas of Macao are shown in five main parts, amounting to approximately $3 \mathrm{~km}^{2}$ of land area (redrawn by the author from the government reports). 
in 2011, after a series of legal challenges and lengthy environmental impact analyses (Tromans, 2012), while the Macao end began in earnest in 2004. The difference in timing reflects a much weaker planning and environmental impact assessment system in Macao compared with Hong Kong, but also reflects differences in the strategic interests of the partners (Yang, 2006; Yang and Li, 2013). Until the bridge, the usual way to travel between these cities was by jet boat or by air. These proposals received rapid approval from Guangdong provincial authorities and the central government, in part because the west side of the Zhujiang River has lagged far behind the east side in economic development. The central government has also publicly exhorted Macao's government to pursue economic diversification, which in the case of the customs port, takes the form of integration in a single controlled facility.

Four of the proposed islands are for urban development while the fifth is the new controlled customs port, under active development in 2014. The other four islands will likely take a form that is quite unusual for Macao or any other waterfront city in South China. To a certain degree, the "islands" idea is a nostalgic reminder that Macao was originally a chain of small islands, now reduced to one through various reclamations. The loss of accessible waterfront in Macao is thus compensated by the addition of a lengthy new waterfront. The waterfront areas $(20 \mathrm{~km})$ will be entirely devoted to green space and will not have motorised transport unlike present-day Macao. The plan specifically calls for pedestrian and bicycle transport in these areas. Note that in the interim the bicycle has virtually disappeared from Macao, replaced by the motorbike. Fully $50 \%$ of the reclaimed land area will be devoted to green and public area, presumably free of the ubiquitous motorbike. A small part of the reclaimed land on island 4 (Figure 1), under the flight path to the airport, will be devoted to "creative industry", along with public housing. It is also intended that the main "streets" of the reclamation areas will be green, pedestrianised corridors, with all motor traffic relegated to service lanes located to the rear or underground.

The proposed urban development densities on these islands are high, or equivalent to that of the existing Macao development or, not coincidentally, of Zhuhai. All of these plans present a startling contrast to the existing Macao. Although the area is very small, Macao is awash in motorbikes and, with the rapidly rising incomes of Macao citizens, private cars. Traffic jams on the tiny land area are a daily occurrence and the air quality at street level is usually at unhealthy levels. The existing waterfronts of Macao are poorly managed, and few are accessible to the public. Moreover, pollution from the Zhujiang River washes around Macao, making its offshore water of very poor quality, brownish and turbid. For this reason, the islands plan includes a fresh water body that will be of much higher quality, in addition to the existing water reservoir (Figure 1). The plan sets out an alternative model to existing Macao and if carried out as planned, will be a remarkably different kind of environment. But the plan is also intended to set the tone and provide the infrastructure for transforming the rest of Macao to a more sustainable and low carbon future. The details of that transformation are far into the future. What we can see is the infrastructure planned to make such a transformation possible, as discussed in the following section.

\section{Case description}

The reclamation plan, in contrast to previous developments on reclaimed seabed, makes intensive use of underground space, or in this case space below mean sea level. The underground space of the new islands has four functions:

1-Residential development dominates the whole plan, in keeping with much of the real estate-led growth of Mainland cities (Wang, 2014). Although planning documents emphasise the dearth of housing for work permit inhabitants while Macao citizens are relatively well housed, this new housing is clearly destined for the luxury market. Isolated by water from existing Macao and largely connected by underground tunnels, parking garages and local facilities, such plans read as virtual gated communities. The plans include technical innovations, in particular the relegation of all motor traffic to subterranean levels, but such innovative ideas, if realised, are also very typical of contemporary urban residential developments on the Mainland. Contemporary marketing strategies for housing developments emphasise abundant vegetation, water features and recreational possibilities, achieved largely through taller buildings on smaller footprints. Whether such approaches constitute a legitimate environmental agenda, as the discourse suggests, remains questionable (Chang and Sheppard, 2013).

2-Island 4 will house a vastly expanded shopping environment, office buildings, more housing and car parking facilities (Figure 2). Macao lacks a luxury goods shopping hub as exists in Hong Kong. The strategy is to diversify beyond gaming to shopping, although the 2014 crackdown on corruption on the Mainland has resulted in a sharp drop in the market for luxury brands. Most of the underground space on this reclaimed island will be devoted to car parking, encasing the planned underground metro line. Island 4 in particular exemplifies the effort on the part of the government to meet needs of the local population through a public space venue and metro, while attempting to capture yet more capital outflows from the Mainland. 


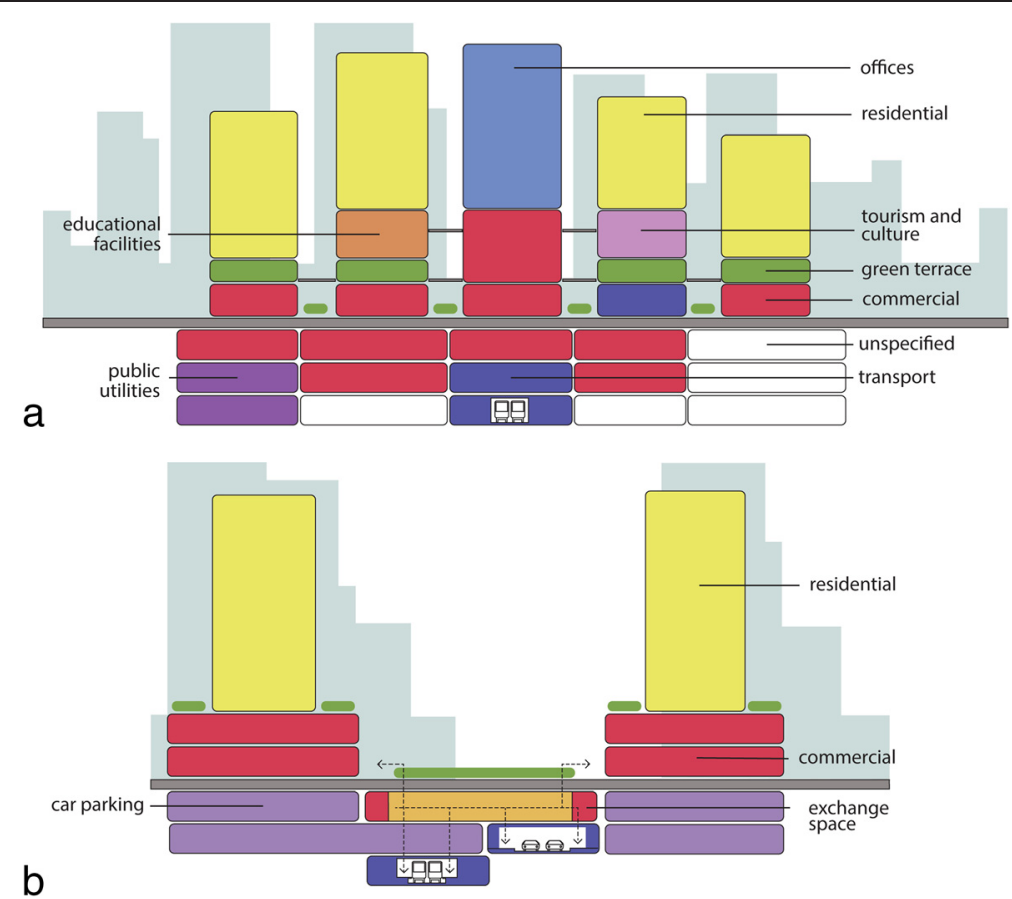

Figure 2 Schematic three-dimensional land use configuration and relationships on Island 4. (Redrawn (a) and interpreted from renderings (b) by the author).

3-The light rail transit (LRT) system is partially completed and is clearly intended to serve Mainland gamblers, since it by-passes residential areas to connect the casinos with the port of entry (Figure 3). The LRT has been hotly contested in the local media. The planned metro line is intended to meet the needs of locals travelling to the planned shopping and commercial hub.

4-Macao will need new public utilities. In particular, Macao needs to conserve water and to recycle water wherever possible since it not self-sufficient in water resources. Its drinking water is sourced ever farther away in Guangdong province as natural supplies and quality on the Mainland decline. In addition, a burgeoning urban population over the border in Mainland China means there is increasing competition for scarcer water resources. Thus, it is intended to create underground cisterns for water retention. Also, new power stations will be located underground, along with warehousing.

From a technical standpoint, the land reclamation programme will facilitate the creation of these underground facilities. Typically, a retention dike is constructed in the sea before the water is pumped out. Consolidation of the seabed for construction can then proceed, with further excavation where necessary. Fill is transported by barge from the Zhujiang River in China. Although it is estimated that the costs of such sea reclamation are substantial, in part due to geotechnical concerns for heavy, urban construction, it is still much less expensive than underground construction on existing land. It is for this reason that Macao has preferred to proceed with its first phase of underground development on reclaimed seabed.

\section{Duplo circulo et duplo eixo}

It is largely through underground development that Macao hopes to create this green open space and car-free waterfront. A circle route is proposed at the fringes of the islands consisting of a double tunnel, accommodating cars in one instance and the metro in another. Two such underground ring roads are proposed. This double circular system will be part of a three-dimensional public transport system for Macao. At the moment, there is only a public bus system on the ground, although it provides good coverage, is very inexpensive and is well liked by locals. The system uses small buses in order to negotiate the tortuous street system. The elevated LRT began construction in March, 2012, near the border crossing to Mainland China, although as can be seen in Figure 3, it is a peripheral line designed largely to serve the casinos. While Macao's air quality has declined sharply as a result of a plethora of casino coaches transporting arriving gamblers free of charge to the casinos, the hope is that the elevated LRT will replace them. It is also hoped that this complex public transportation system at three levels will convert Macao from private transportation to a public system. In this sense, it follows the plan of Taipei, Taiwan, where a three-level system has also been built.

The real challenge will be the reduction in motorbike traffic, which, like the casino buses, has contributed to 


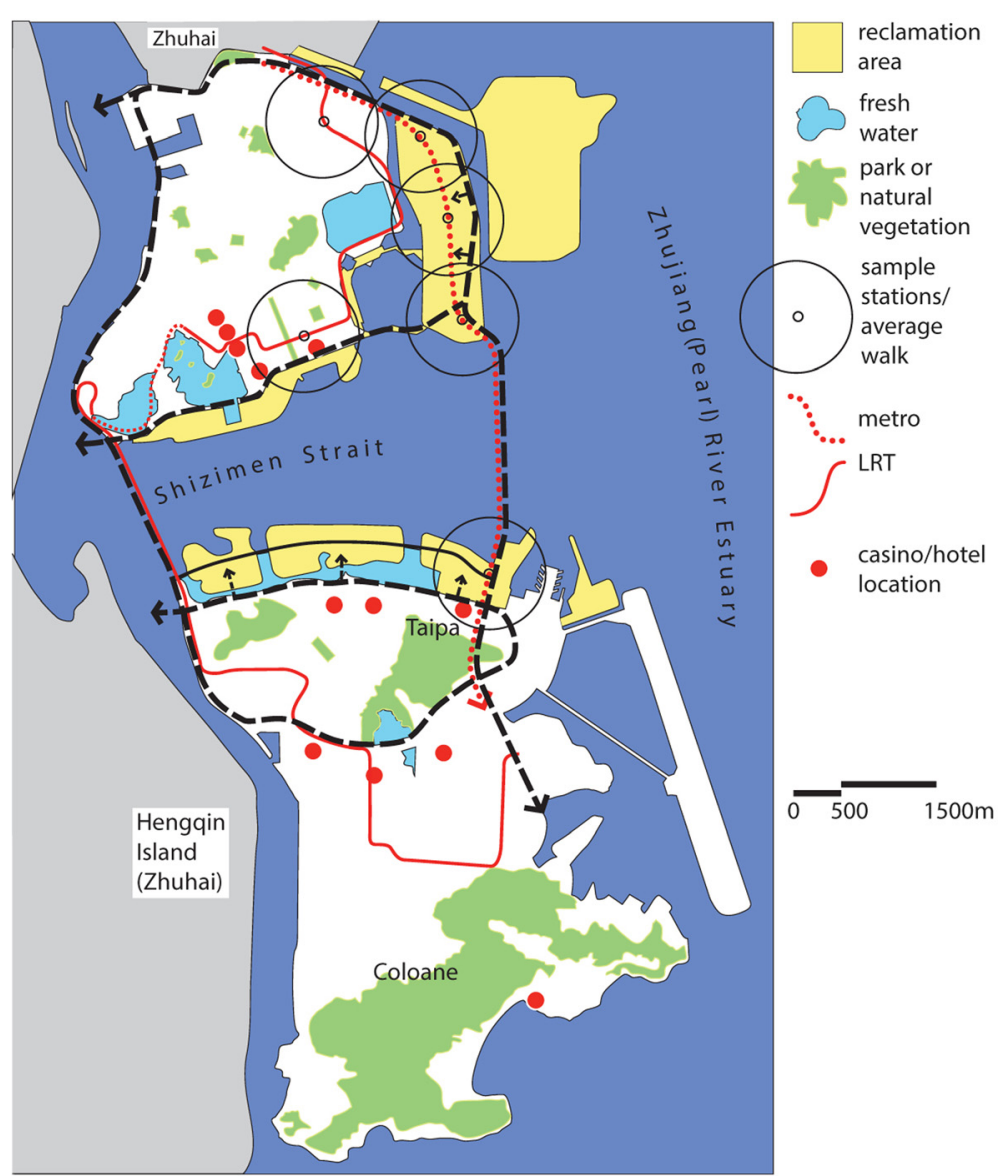

Figure 3 The LRT, metro and new underground roads plan. The circles represent mean walking distance from an unpublished survey conducted by the Urban Planning Institute. (redrawn by the author from government reports).

noise and air pollution. Motorbikes became increasingly popular over the 2000-2010 decade because of the limited road network but also the scarcity of car parking. It is somewhat ironic that Macao, with the highest per capita income among cities in Greater China and Asia, is the only one with such a massive fleet of motorbikes. Prevailing neo-liberal approaches of local authorities lead planners to offer viable alternatives, like the metro and LRT, but it remains less than certain that these highgrade alternatives to getting around will actually lead to modal shift. There is no announced plan for the reduction of motorbike use other than the provision of these alternatives. Although large parts of the developed territory could be served by non-motorised transport (Figure 3), walking conditions tend to be poor. There are many pedestrian bridges and poorly regulated pedestrian crossings at grade, making the walking experience uncomfortable if not perilous.

The tunneled circular road will provide access to underground garages on the islands. Island 4, adjacent to the customs port, is also intended to develop as an underground commercial level similar to that in Montréal. This two-level system will have a surface environment given over to pedestrians, shopping and leisure activities, while the level immediately below, and above the metro line, will house shopping. The metro will then continue under the Shizimen strait and service the remaining three islands off the north coast of Taipa.

If successful and carried out as planned, this underground circulation system will be the largest in the world, far exceeding Boston's Big Dig. The new developments will be very different in character and function from the rest of Macao. By taking this step, it is clear that the plan is intended to be a low-carbon model for revitalisation of the rest of Macao. The form that such a revitalisation effort could take is not yet clear, given the morphology of the UNESCO site and the conventional patterns of development on the earlier reclamation sites, but is challenging to contemplate. The plans do not elaborate on this hoped-for sustainable future, probably because the policy changes that would make it possible are difficult in the present socio-political context.

The Macao plan also proposes a much closer physical integration with Zhuhai. The underground road tunnels 
are intended to connect directly to Zhuhai such that the new islands become an extension of Zhuhai's planned Shizimen CBD. The new housing of Macao has to be read as a high-quality extension of the proposed Zhuhai CBD, even if there remains a formal customs and immigration border, the official spoken languages are different, and traffic moves in opposite directions on each side of this border (Figure 3). Macao's bid to free itself from the gambling umbilical cord somewhat ironically involves forging even stronger relations with the Mainland. Whether the reclaimed territory contributes to redefining economy and society in Macao, or becomes instead an offshore playground for wealthy Mainlanders remains an open question. To some observers, the new consumerist landscape ties Macao ever more firmly to a mainland still gripped by a producer economy and in need of occasional escape (Simpson, 2008).

\section{Discussion and evaluation}

Macao's vision of a car-free, low-carbon, seaside leisure paradise is, of course, an illusion. This utopian vision is really an extension of the promise proffered by casinos that now dominate the Macao landscape. The green paradise on the surface belies the pursuit of motorisation when geography and metrics would seem to call for a non-motorised environment.

Unlike Singapore and Hong Kong, Macao has made no moves in the direction of restricting motor vehicles. Although the land mass is much smaller than these two other island city-states, and with higher population density, Macao has taken a transport pathway closer to that on the Mainland. However, Zhuhai, has not only banned motorbikes but also electric bicycles, while devoting much space to car infrastructure. As incomes in Macao rose rapidly from 2000, people have acquired motorbikes and then cars. The approach in the new development is to use underground space, at least in part, to move and store the cars. The planned flows between Zhuhai and Macao, in contrast with those between Shenzhen and Hong Kong, are motorised. In this sense, the plan is designed to accommodate the market and to implement a synchrony with its Mainland neighbour.

What is in the plan for the Macao population? The LRT in its initial phase will largely serve the casino industry, not everyday activities of the resident population. It will nevertheless be a challenge to wean visitors off the free shuttle buses provided by the casinos at the ports of entry, since the majority of visitors stay in Macao for less than a day. The very expensive undergrounding of the metro does allow the development of a climate-controlled shopping and cultural environment that presently does not exist. It would have been feasible to cover the entire territory with a tram network to replace the minibus system, but it would also require a radical shift of road space to public transport, which in the present political context is difficult. Nor is such topdown management of the local economy part of Macao's history, notable for corrupt local governance and neoliberalism (Luke, 2010). It is entirely in keeping with this historical background that the local government would continue to support a commercialised land market, unregulated motorisation and a two-tier social structure. Only in the interests of maintaining the health of the local casino industry, if not the traditional Macao culinary and service culture, is the government intervening to develop social housing. On the other hand, the physical environment of the proposed expansion areas is radically different from what Macanese can experience in their city today, or by citizens of Zhuhai for that matter. The ground level will be a garden, rather than a tangle of traffic-choked streets. The planning documents make clear that this radical departure in the character of the surface environment is intended to effect a change in local thinking about the environment. This diffusion effect has worked elsewhere.

How could the underground space in the new islands be used? Arguably, two levels could be used effectively for all urban uses-shops, community facilities, education and even habitation by exploiting the elevation difference. Macao has weak road links between north and south. Yet if cars were not used for daily purposes in Macao, these road links would nevertheless be adequate to get cars in and out of Macao, with modest modification of the road network in peninsular Macao.

The hoped-for diversification of the local economy finds no home in the islands scheme except for a tiny "creative industry park" below the flight path to the airport. Arguably, the new campus of the University of Macao, with real and symbolic isolation from the gambling heart via a single tunnel to Hengqin Island, is a step in this direction. In planning undergraduate education in near-rural isolation from urban distractions, it follows a familiar pattern on the Mainland. However, this important investment in education also represents another kind of gamble-that youth can be weaned off easy money and the casino job market.

\section{Conclusions}

In the years following market liberalisation in China, cities were largely left to their own devices to develop. While central government loosened the regulatory framework to allow local governmental and private initiative, provincial authorities exerted little control over urban development. In recent years, however, central government policies have re-asserted themselves in local development. Macao's explosive development could not have occurred without the regulations put in place by the central government. Provincial authority has also returned as an important local 
force, as regional transport networks link cities and new relations are forged between cooperating and competing local entities. Macao's prosperity is arguably dependent on renewed and vigorous intervention on the part of other cities in the PRD, the province and the central government. While Macao enjoys relative freedom on its own territory, with its own financial, legal and educational system, its future is increasingly tied to the Mainland.

The Macao plan reflects this duality of identity in very physical terms. Planning priorities, including the order in which they will be carried out, support economic development and closer integration with the Mainland. A richer Macao in the short run is accompanied by the promise of longer-term improvements to the public environment, starting with a few highly visible projects on new territory. In this sense, Macao has adopted much the same strategy as the vast majority of Mainland cities, where rapidly deteriorating environmental quality is accompanying a rise in personal disposable income for those with urban resident rights.

As the literature on cross-border integration shows, localities assume or are assigned roles in a complex and highly hierarchical regional structure. Macao has clearly decided to play a supporting role in the integration with its Mainland neighbours as a leisure and entertainment venue but also as a place to enjoy the good life. The rising proportion of relatively low-income migrant workers needed to support this good life could be the source of significant future tensions, as other cases demonstrate (Timberlake et al., 2014). Just what young graduates of the universities in Macao will do, besides working in the service industry, remains unclear since there is no plan for the development of an alternate economy and indeed no place where it could flourish. The current Five Islands plan, like many launched throughout China, is heavy on imagery and light on process.

The Macao utopian future, as suggested in this paper, may be a chimera, like most of the claimed sustainable urban developments on the Mainland (Chang and Sheppard, 2013). The appearance of utopia in a moment of suspended disbelief, underwritten by the massive profits of gambling, serves Macao's present and future as a playground for Mainlanders. A plantation forest of high-rise housing (islands 1, 2, 3 in Figure 1) bears little relation with the region's rich architectural legacy, but serves a marketing strategy aimed perhaps at local investment opportunities, perhaps at Mainlanders if the present acquisition rules are relaxed. The islands promise a green paradise for recreation, but are largely isolated and inaccessible to Macao's present population. But, as the planning documents emphasise, it may be that the realisation of such a utopian vision may spur on a genuine project for a sustainable and livable Macao.

\section{Competing interests}

The author declares having no competing interest.

Received: 9 April 2014 Accepted: 23 December 2014

Published online: 23 January 2015

\section{References}

Allock C (2000) A background to problem gambling. Australas Psychol 8(3):253-255

Balsas C (2013) Gaming anyone? A comparative study of recent urban development trends in Las Vegas and Macao. Cities 31:298-307

Brenner N (2004) New state spaces: urban governance and the rescaling of statehood. University Press, Oxford

Bristow R (1989) Hong Kong's New Towns: a Selective Review. Oxford University Press), Hong Kong

Brunet-Jailly E (2005) Theorizing borders: an interdisciplinary perspective. Geopolitics 10(4):633-649

Chang C, Sheppard E (2013) China's eco-cities as variegated urban sustainability: Dongtan Eco-City and Chongming Eco-Island. J Urban Technol 20(1):57-75

Hao Z (2011) Macao history and society. Hong Kong University Press, Hong Kong Huang C-H, Tsaur J-R, Yang C-H (2012) Does world heritage list really induce more tourists? Evidence from Macao. Tourism Manage 33:1450-1457

Hsu C, Gu Z (2010) Ride on the gaming boom: how can Hong Kong, Macao and Zhuhai join hands to develop tourism in the region? Asia Pac J Tourism Res 15(1):57-77

Li Z, Xu J, Yeh AG (2014) State rescaling and the making of city-regions in the Pearl River Delta, China. Environ Plann C Gov Policy 32:129-143

Luke TW (2010) Gaming space: casinopolitan globalism from Las Vegas to Macao. Globalizations 7(3):395-405

Luo X, Shen J (2012) The making of new regionalism in the cross-boundary metropolis of Hong Kong-Shenzhen, China. Habitat Int 36:126-135

Macao (2012). Secretaria Para os Transportes e Obres Públicas do Governo da RAEM. Antepojecto do Plano Director das Novas Zonas Urbanas Texto para Consulta. 2a Fase de Auscuitaçao Pública do Plano Director das Novas Zonas Urbanas. Macao: Macao Government.

Otgaar A, van den Berg L, van der Meer J, Speller C (2008) Empowering metropolitan regions through new forms of cooperation. Ashgate, Abingdon

Petry NM (2003) Patterns and correlates of gamblers anonymous attendance in pathological gamblers seeking professional treatment. Addict Behav 28 (6):1049-1062

Rato R and Davey G (2012) Quality of life in Macau, China. Soc Indic Res 105:93-108.

Sassen S (1991) The global city: New York, London, Tokyo. Princeton University Press, Princeton

Shen J (2014) Not quite a twin city: cross-boundary integration in Hong Kong and Shenzhen. Habitat Int 42:138-146

Simpson T (2008) Macao, capital of the $21^{\text {st }}$ century? Environ Plann D 26:1053-1079

Statistics and Census Service (2014) General Statistics, retrieved October 10, 2014 from http:www.dsec.gov.mo/statistic.aspx

Timberlake M, Wei YD, Ma X, Hao J (2014) Global cities with Chinese characteristics. Cities 41:162-170

Tromans S (2012) EIA in Hong Kong: some thoughts on the Hong Kong-ZhuhaiMacao bridge case. J Plann Environ Law 22:1304-1316

Wan YKP (2012) The social, economic and environmental impacts of casino gaming in Macao: the community leader perspective. J Sustainable Tourism 20(5):737-755

Wang $L$ (2014). Forging growth by governing the market in reform-era urban China. Cities, 41:187-193

Yang C (2006) The geopolitics of cross-boundary governance in the Greater Pearl River Delta, China: a case study of the proposed Hong Kong-Zhuhai-Macao Bridge. Pol Geogr 25:817-835

Yang C, Li S-M (2013) Transformation of cross-boundary governance in the Greater Pearl River Delta, China: contested geopolitics and emerging conflicts. Habitat Int 40:25-34 